\title{
Entrevista Ricardo Vargas
}

\section{Em sua opinião, o Gerenciamento de Projetos pode ser considerado um fenômeno global? Como ele surgiu?}

O Gerenciamento de Projetos se tornou um evento e um trabalho extremamente importante porque sua aplicabilidade aumentou violentamente. Hoje em dia, as organizações têm muito menos rotina e muito mais projeto. Ele surgiu, basicamente, nos movimentos dos processos produtivos. No início, o grande foco do gerenciamento de projetos era o foco industrial. Hoje temos um gerenciamento de projetos mais distribuído em outras áreas de conhecimento.

Quais são os benefícios da inserção de uma cultura de Gerenciamento de Projetos dentro de uma organização?

O principal benefício é preparar as organizações, de uma forma correta e competente, para trabalhar a mudança. As empresas, hoje, atuam, muito mais, por projetos do que por processos e por rotinas. A rotina, normalmente, é mecanizada e automatizada. Um projeto, dificilmente, será automatizado, porque sua carga de inovação e de riscos necessitará sempre de pessoas com capacidade crítica para poder decidir sobre esse projeto.

\section{Como se encontra, atualmente, o grau de maturidade em Gerenciamento de Projetos no Brasil, em comparação com os Estados Unidos?}

Sem dúvida nenhuma, nós temos evoluído muito. Diria que nós temos evoluído a uma taxa maior do que em outros países. É lógico que não podemos comparar a nossa maturidade com a maturidade americana. Nos Estados Unidos, o gerenciamento de projetos é parte do trabalho natural das organizações, há muito tempo. Alcançamos, agora, o marco de dez mil membros no PMI. Nós temos cerca de quinze mil profissionais certificados. Trata-se de um número crescente, mas nós ainda temos um ótimo e um longo caminho a andar, que faz parte do nosso próprio desenvolvimento como país.

\section{Como foi fundado o Project Management Institute (PMI) e de que forma esta associação contribui para um quadro evolutivo do Gerenciamento de Projetos no cenário brasileiro?}

O PMI tem 42 anos. Assim, nós não estamos falando de um instituto novo. Ele foi fundado a partir de um grupo de voluntários que acreditou que o gerenciamento de projetos podia contribuir para as organizações de uma forma mais efetiva. Como instituição sem finalidade lucrativa, seu grande objetivo é garantir que as organizações sejam bem sucedidas nos projetos e que elas alcancem resultados por meio deles. Com isso, o PMI provê padrões, certificação e networking para que as organizações percebam cada vez mais o gerenciamento de projetos e alcancem maior sucesso através deste caminho. 